\title{
䯣液鼻漏の診断と治療
}

\author{
兵頭 政光・湯本 英二・佐伯 克哉 \\ 堀内 譲治・柳原 尚明
}

\section{Diagnosis and Surgical Treatment of Cerebrospinal Fluid Rhinorrhea}

\author{
Masamitsu Hyodo, Eiji Yumoto, Katsuya Saeki, \\ Jyoji Horiuchi and Naoaki Yanagihara \\ (Ehime University)
}

\begin{abstract}
Cerebrospinal fluid (CSF) rhinorrhea is potentially serious because it may lead to recurrent meningitis. Therefore, early diagnosis and appropriate treatment of CSF rhinorrhea are required.

We treated 13 patients with CSF rhinorrhea during the past 15 years. Four of them had meningitis. All 13 were successfully treated surgically with a rhinological approach in 12 and an intracranial approach in one. On the basis of our experience, RI counts of intranasal pledgets and detection of tau-transferrin in the nasal discharge were helpful in the diagnosis of CSF rhinorrhea. A coronal CT scan was useful in the determination of the precise location of the fistula.

For a surgical treatment, a rhinological approach with minimal morbidity was indicated in most patients. Key points of the operation are : 1) careful observation of the fistula under an operating microscope or a rigid nasal endoscope, 2) water-tight closure of the fistula with fibrin glue and two or three layers of autogenous fascia, 3) intra-and postoperative CSF drainage to prevent an increase of intracranial pressure.
\end{abstract}

Key words : CSF rhinorrhea, rhinological approach, RI count, tau-transferrin, rigid nasal endoscope

\section{はじめに}

䯣液鼻漏は長期間持続すると化膿性髄膜炎を反復する 危険性があり ${ }^{122)}$ ，早期の診断と適切な治療が求められ る.

当科ではこれまでに手術的治療を要した䯣液鼻漏症例 を13例経験した。これらの経験より，診断においては脳 槽シンチグラフィー時の鼻腔内留置タンポンの RI カウ ントと，採取した鼻漏中の䯣液特異タンパクであるタウ トランスフェリン (tau-transferrin) の同定が有用であっ た。をた手術用顕微鏡や硬性鼻内視鏡の使用により, 術 中に瘻孔の部位と状態をより詳細に観察し, 確実に瘦孔 の閉鎖を行らことができた。
今回, われわれが行っている䯣液鼻漏の診断と治療の 要点について, 代表例を呈示して報告する.

\section{対 象}

愛媛大学附属病院耳鼻咽喉科にて過去 15 年間に手術的 治療を行った骨道液鼻漏症例13例を表 1 亿示す. 原因は外 傷性 4 例, 術後性 6 例, 特発性 2 例, 髄膜脳瘤 1 例であ った．前頭蓋底手術後の例は篩骨洞癌の頭蓋内進展例と， 悪性䯙膜腫の副鼻腔進展例である. 䯣膜脳瘤の例は外傷 に起因したものであり詳細は別稿にて報告した3). これ らのうち 3 例で化膿性髄膜炎, 1 例で化膿性髄膜炎と気 脳症の合併があった。診断には鼻腔内留置タンポンの 
RI カウントを 7 例に行い, いずれも髄液漏を確認した. また鼻漏中のタウトランスフェリン同定を4 例に試み, 3 例で陽性所見を得た。治療は12例は経鼻副鼻腔法(頭 蓋外法)で，1 例は頭蓋内法で行い，いずれも髄液漏を 停止させることができた。

次にこのららの代表例(症例 6 )を呈示する.

\section{症例}

患者：36歳，男性.

主訴：右水様性鼻漏.

現病歴：昭和61年に慢性副鼻腔炎にて，某病院で両側 上顎洞篩骨洞根本術および鼻中隔矯正術を受けた。術後 は特に異常なく経過していたが，約 1 年半後より誘因な く右水様性鼻漏が出現し持続するよらになった。アレル ギー性鼻炎として内服加療を受けるも鼻漏は不変であっ た。その後，他院でテステープ法により鼻漏中に糖を認 めたため, 髄液鼻漏を疑われ平成 2 年 10 月当科を紹介さ れた。な経過中，他の鼻症状执よび髄膜炎症状はない。

既往歴, 家族歴 : 特記事項なし.

現症 : 鼻鏡所見では右中鼻甲介は手術により大部分切 除されて接り，基部がわずかに残存するのみであった。 右篩骨洞は十分に開放されて抎り，中鼻道拉よび総鼻道 に相当する部位に少量の漿液性鼻漏を認めた。な扔左鼻 腔には著変なかった。硬性鼻内視鏡により鼻内を詳細に
観察すると, 右前部篩骨洞の中鼻甲介基部に拍動を有す る孤立性のポリープ様病変を認め, その周囲より透明な 漿液性の液がわずかに流出していた。

検査所見 : 副鼻腔断層撮影で右前部篩骨洞天蓋に骨欠 損を疑わせる部位があり，冠状断 CT ではこの骨欠損が より明らかでポリープ様の軟部組織陰影も認めた(図 1). ${ }^{111} \mathrm{In}-\mathrm{DTPA}$ にる脳槽シンチグラフィーでは明ら

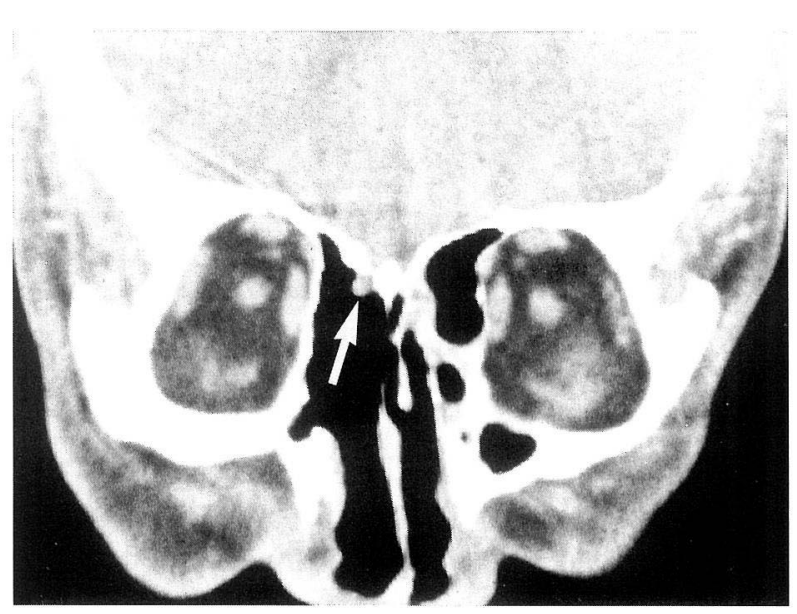

図 1 冠状断 CT 所見

右前頭蓋底の骨欠損特よび篩骨洞に突出する軟部組織陰 影を認める $(\rightarrow)$.

表 1 手術的治療を行った髄液鼻漏症例

\begin{tabular}{|c|c|c|c|c|c|c|c|c|c|}
\hline No. & 症例 & 年齢 & 性 & 原因 & 漏出部位 & 合併症 & RI & $T-T f$ & 手術法 \\
\hline 1 & & 20 & 男 & 外傷（交通事故） & 左前部篩骨洞 & 䑷膜资 & $N$ & $N$ & 鼻外前頭洞経由 \\
\hline 2 & & 35 & 女 & 外傷（交通事故） & 右前頭洞、前部笁骨洞 & & + & $\mathrm{N}$ & 鼻外前頭洞経由 \\
\hline 3 & & 9 & 女 & 外傷（転落） & 左前頭洞 & 髄膜炎 & + & $N$ & 鼻外前頭洞法 \\
\hline 4 & & 68 & 男 & 外傷（転落） & 右前部籂骨洞 & & + & + & 鼻外前頭洞経由 \\
\hline 5 & & 53 & 女 & 術後性（後部節骨・蝶形骨洞囊胞） & 右後部篩骨洞 & & $N$ & $N$ & 鼻外前頭洞経由 \\
\hline 6 & & 36 & 男 & 術後性（慢性副鼻腔炎） & 右前部管骨洞 & & + & + & 鼻外前頭洞経由 \\
\hline 7 & & 60 & 男 & 術後性（上顎癌） & 右管骨洞 & & $\mathrm{N}$ & $N$ & 鼻側切開 \\
\hline 8 & & 65 & 男 & 術後性（上顎癌） & 右篩骨洞 & & $N$ & $N$ & 鼻側切開 \\
\hline 9 & & 65 & 男 & 術後性（前頭蓋底手術） & 前頭蓋底 & 髄膜炎、気脳症 & $\mathrm{N}$ & + & 頭蓋内法 \\
\hline 10 & & 41 & 男 & 術後性（前頭蓋底手術） & 前頭蓋底 & & $N$ & - & 鼻側切開 \\
\hline 11 & & 30 & 女 & 特発性 & 左前部斾骨洞 & 髄膜炎 & + & $N$ & 鼻外前頭洞経由 \\
\hline 12 & & 64 & 女 & 特発性 & 左前部篩骨洞 & & + & $\mathrm{N}$ & 鼻外前頭洞経由 \\
\hline 13 & & 48 & 男 & 髄膜脳瘤 & 左前頭洞 & & + & $N$ & 鼻外前頭洞法 \\
\hline
\end{tabular}

$R \mid$ : RIカウント法, T-Tf : タウトランスフェリン, N : 未㭘査 
かな髄液漏の所見は認めなかったが，同時に施行した鼻 腔内留置タンポンの RI カウントでは左鼻腔 $(1,298$ cpm) に比し右鼻腔 $(23,685 \mathrm{cpm})$ で著明な高値を示した。 また右鼻腔内にメローセル®を一晚留置して採取した鼻 汁より，タウトランスフェリンを検出した(図 2 )。これ らの結果より, 副鼻腔手術時の前頭蓋底損傷に起因する 遅発性髄液鼻漏と診断し以下の手術を行った。

手術所見：手術は全身麻酔下に鼻外法と鼻内法の併用 で行った．腰椎穿刺により䯣液持続ドレナージを行った 後，顕微鏡下に前頭洞経由で前部篩骨洞に達した。同部 の粘膜は注ぼ正常であったが，球状で表面平滑なポリー プ様組織が頭蓋底部より突出していた(図 $3 \mathrm{a}$ )。これは

a

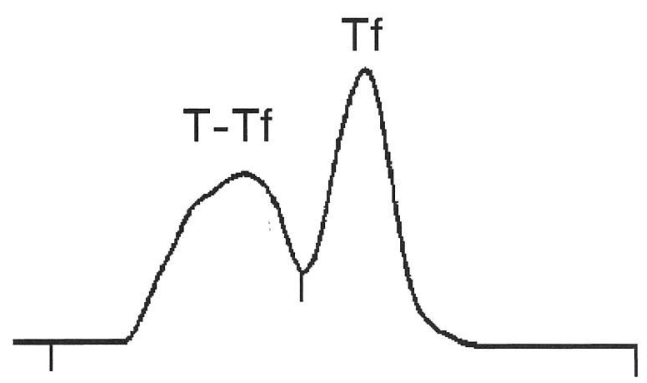

$\mathrm{Tf}$

b

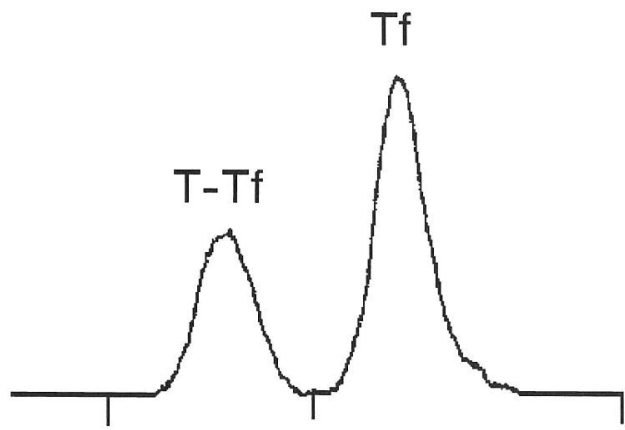

\section{$\mathrm{Tf}$}

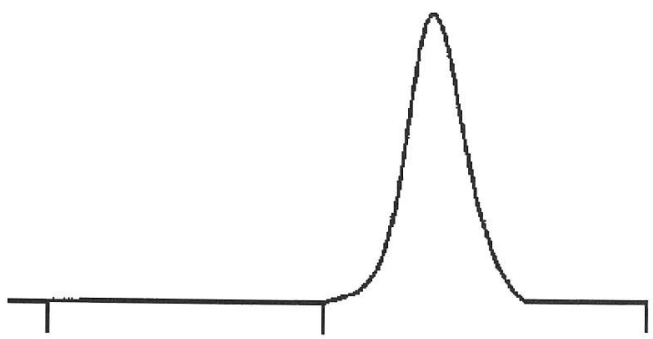

図 2 鼻漏の電気泳動所見

$\mathrm{a}$ ：トランスフェリン $(\mathrm{Tf})$ の陰極側にタウトランスフ ェリン (T-Tf) を認める。髄液 ( b ) 和よびアレルギー性 鼻炎患者の鼻漏 $(\mathrm{c})$ を対照として示す。
拍動を有し，その周团より髄液の漏出を認めた。ポリー プを基部で切断すると硬膜に径が約 $2 \mathrm{~mm}$ の瘦孔を認め たため(図 3 b)，一旦髄液圧を下げた後，瘻孔にオキシ セル®綿を充填し髄液漏を停止させた。ささらに同部にフ ィブリン接着剤を用いて大腿筋膜を接着し, 髄液漏が完 全に停止したことを顕微鏡および内視鏡下に確認した。 さらにその上に笳膜を重ねて接着し，閉鎖をより確実な

a

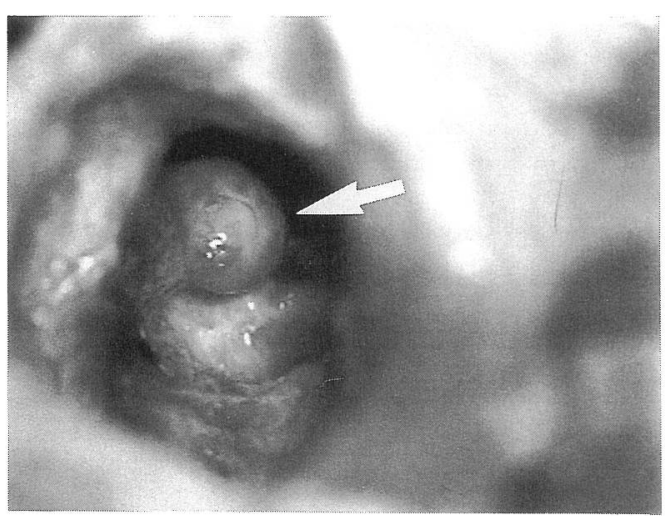

$\mathrm{b}$
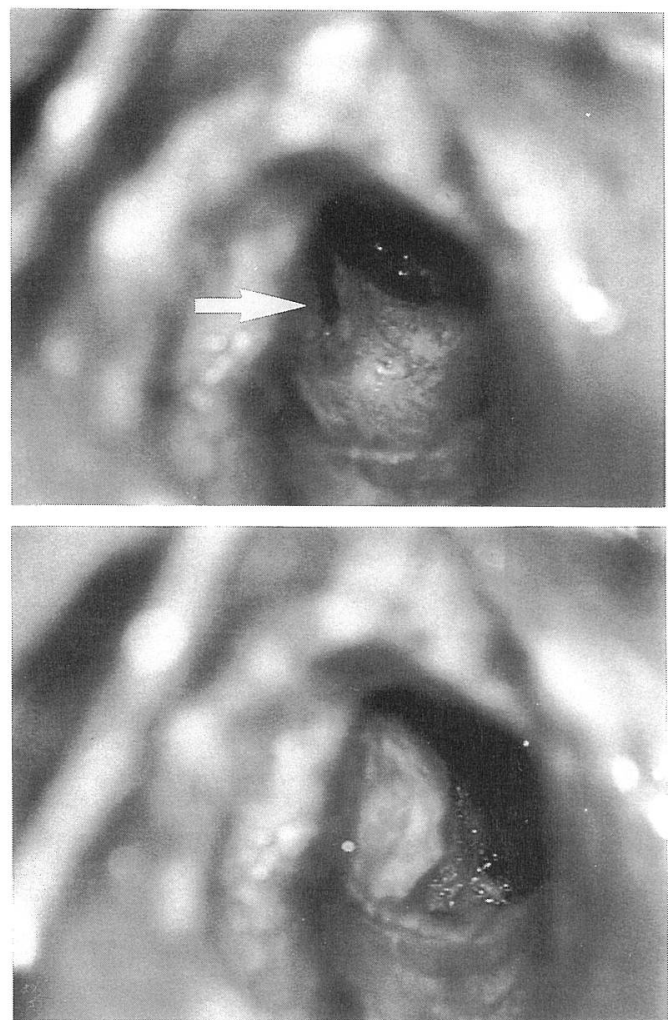

図 3 手術所見

a：節骨洞天盍よりポリープ様組織が突出している $(\rightarrow)$. b : ポリープ様組織の切断後, 硬膜に瘻孔を認める $(\rightarrow)$. c：瘦孔を筋膜で三重に閉鎖した。 
ものとした(図 $3 \mathrm{c}$ )。髄液持続ドレーンは術後 8 日間留 置し，内視鏡下に髄液漏のないことを確認のら光拔去し た。な拈切除したポリープ様組織の病理組織検査では, 炎症反応を伴った脳組織および髄膜が認められた，術後 3 年 6 カ月を経過した現在, 髄液漏の再発を認めていな い.

\section{考察}

Ommaya 5 4) は䯣液鼻漏を外傷性と非外傷性に分け, さらに前者を事故によるものと術後性(医原性) そ細分し た.これらのらち従来は事故によるものが多いとされて きたが ${ }^{11)}$, 近年では頭蓋底手術例の増加に伴い術後性の ものが増加傾向にある.

本症では原因の如何にかかわらず，髄膜炎などの合併 症を未然に防ぐためにも早期診断が重要である，鼻漏は 通常，一側性で頭位により量が変化する．われわれの経 験でも，下を向いて腹圧をかけると一側の前鼻孔からポ タポタと水様性の鼻漏が滴下寸る例が少なからずあった． このよらな症状より䯣液漏を疑い，外傷や手術などの原 因が明らかでない場合は再度詳細に問診を行ら必要があ る. 幼小児期の外傷に起因寸る遅発性発症もあり，家族 から問診を行らことも必要である．なかには外傷後41年 を経て発症した遅発例の報告もあり5)，われわれも外傷 後約60年を経過して発症した例(表 1 の症例 4 )を経験し た。な拉本症はその症状より，アレルギー性鼻炎などと 誤って長期間治療を受けていることもあり注意を要する.

䯣液漏の診断法として, 鼻漏中の糖を検出するテス テープ法は簡便ではあるが，微量の䯣液漏では陽性に出 にくいし，涙液や鼻汁中にも糖は含まれるため疑陽性も 多(6)。スクリーニング法または補助診断法と位置づけ るのが妥当であろう。

脳槽シンチグラフィーは䯣液漏が少量の場合は陽性率 が低く，それのみでは診断的価値は高くない. Crow ら ${ }^{6)}$ は脳槽シンチグラフィーの際に鼻腔内に糸付き綿花 を留置し，一定時間後に綿花の RI 活性を測定すること により䯣液漏の有無を診断する方法を報告した。本法は その後, 諸家78) そより有用性が報告され，われわれ9110) もこの方法により高い診断率を得ている。この際に注意 すべきは䯣腔内に注入した RI は血行あるいは嗅神経の perineural space を介して正常の鼻腔内にも出現するた め, 健側と比較する必要がある点である.

一方, Meurman ら ${ }^{11)}$ は䯣液漏の診断にタウトランス
フェリンの同定を提唱した.トランスフェリンは生体内 で鉄の運搬を行う分子量約 80,000 の糖タンパクであるが， これは電気泳動によりいくつかの分画に分けることがで きる.このうちタウトランスフェリンはトランスフェリ ンの陰極側で $\tau$-band としてみられ，タンパク分画では $\beta_{2}$ 分画に位置するため $\beta_{2}$ トランスフェリンとも呼ばれ る。これは髄液中にのみ存在し血液, 沪液, 鼻汁, 唾液 などには認められない11)(図 2 )。従って鼻漏または耳漏 中にタウトランスフェリンを認めれば，それは䯣液を含 むことを意味し䯣液漏の診断に秃いてきわめて有用であ $ろ^{12) 13)}$.

タウトランスフェリンの同定は，採取した検体の高速 遠沈, 電気泳動, 免疫固定, 銀染色の過程を経て行われ る。本法は非常に鋭敏で純粋な䯣液ならば $1 \mu 1$ (約 $1 /$ 50 滴)あれば, もしくは $1 \mathrm{ml}$ の検体中に $100 \mu \mathrm{l}$ (約 2 滴） の䯣液が含まれれば検出可能とされている13). 本法は検 查時の侵襲が注とんどないため反復検査が可能で，術前 後で容易に比較することができる利点もある12)，当科で は数年前より髄液鼻漏疑いの患者に対しては, タウトラ ンスフェリン同定をルーチンに行って招り，これまで 9 例に対して本検査を行った。 このらち表 1 亿示す 3 例で 陽性所見を得た。な拉 1 例が偽陰性であったが，これは 検体の採取後の 1 日間, 冷所保存を意ったことが原因と 考光ている。

漏出部位診断に扣いて画像診断が重要なことは言うま でもない。このうち従来は断層撮影が重要な役割を担っ ていたが9), 近年では高分解能 CT の発達により冠状断 CT がより有用と考壳ている。従来の軸位断 CT に上る 部位診断は多くの場合困難である.さらには 3 次元 CT の普及により，今後瘦孔の部位と大ささは上り詳細に術 前診断できるものと期待される．MRI は頭蓋底の骨欠 損が描出できない欠点はあるが，䯣液鼻漏の原因となり らる腫瘍や髄膜脳瘤などの病变の診断には有用である.

治療は外傷性髄液鼻漏では半数以上が 1 週間以内に自 然停止するとされ14)，発症早期は保存的治療を行い髄液 漏が 2 週間以上持続する場合は手術を行らべきと考光る。 保存的治療では安静が重要で, 髄液持続ドレナージによ る䯣液圧上昇の防止も効果的である.非外傷性髄液鼻漏 は通常, 発症後長期間を経て受診することが多く, 保存 的治療の対象となる例は限られる.

手術のアプローチ法には，頭蓋内法と頭蓋外法すなわ ち鼻副鼻腔経由法とがある，開頭による頭蓋内法は，硬 
膜損傷部位を明視下に括いて広い術野で瘦孔の閉鎖を行 らことができる利点がある。髄液漏が多いかまたは多発 性の場合, 前頭蓋底手術後の例などでは本法が必要と考 える。しかし手術侵襲が大きく, 再発率も決して少なく ない15)。また手術により少なくとも患側の嗅覚障害が起 きる欠点もある10).

鼻副鼻腔経由法は従来は視野が狭く, 手術効果も確実 性に欠けるとされてきた。しかし侵襲の少ない本法によ り髄液鼻漏を停止させようとする試みは1948年の Dohlman ${ }^{16)}$ 以来多くの報告があり, 手術法の工夫によ り頭蓋内法と比べても遜色ない手術成績が得られるよう になってきた ${ }^{17)}$. 最も重要なことは瘦孔をいかにして明 視下に置くか，といら点である.このためには手術用顕 微鏡下の観察が不可欠であるが，われわれは最近では硬 性内視鏡による観察も併用している. 硬性内視鏡には直 視型のほか各種の斜視型があり, 顕微鏡での観察が困難 な後部篩骨洞や蝶形骨洞などの病変を詳細に観察するこ とができる。また内視鏡下に鼻内法のみで瘦孔の閉鎖を 行った報告もみられる18).

瘦孔の閉鎖は，まず周囲の肉芽組織や粘膜を搔爬した 後, 瘦孔にオキシセル®綿などを充媜する. 次いで㾇孔 を筋膜で覆い，それをフィブリン接着剤を用いて接着し 髄液漏が停止することを確認する。ささらに筋膜を重ねて 接着し閉鎖をより強固なものにする.

髄液持続ドレナージは, 術中拉よび術後の髄液圧上昇 を防止し筋膜の閉鎖効果を保つ上で極めて有効であ

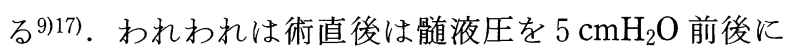
設定し，䯣液の流出量をみながら設定圧を $5 \sim 6$ 日かけ て $20 \sim 25 \mathrm{cmH}_{2} \mathrm{O}$ まで上げた後抜去するようにしてい る.

以上のような点に留意すれば，多くの症例で侵襲の少 ない鼻副鼻腔経由法にても䯣液鼻漏の確実な停止が可能 であり，われわれ耳鼻咽喉科医の果たす役割はさらに大 きくなるものと思われる.

\section{まとめ}

1. 当科に和いて過去 15 年間に, 手術を要した䯣液鼻 漏症例を13例経験した．䯣液漏の原因は外傷 4 例, 術後 性 6 例, 特発性 2 例, 髄膜脑瘤 1 例であった.

2 .診断には詳細な問診のほか, 脳槽シンチグラフィー 時の鼻腔内 RI カウント法, 鼻漏中のタウトランスフェ リン同定が有用であった。部位診断に执いては冠状断
CTが有用であった。

3. 治療は12例は鼻副鼻腔経由法，1例は頭蓋内法で 㾇孔の閉鎖を行い，いずれも再発を認めていない，鼻副 鼻腔経由法の要点は,

(1)手術用顕微鏡または鼻内視鏡により瘦孔の部位と大 きさを詳細に観察し，また術後の閉銷効果を確認するこ と

(2)㾇孔は筋膜をフィブリン接着剤を用いて数重に貼り 合わせて閉鎖すること

(3)髄液持続ドレナージを併用すること などである。

本論文の要旨は, 第19回日耳鼻四国四県地方部会連合学会 (1993年 6 月, 徳島市), 第56回耳鼻咽喉科臨床学会(1994年 7 月，鹿児島市)に执いて口演した。

なおタウトランスフェリンの同定は株式会社 BML のご好意 により行われた、稿を終わるにあたりここに深謝いたします。

\section{参考文献}

1) Westmore GA and Whittam DE : Cerebrospinal fluid rhinorrhoea and its management. Br J Surg $69: 489 \sim 492$, 1982.

2 ）野村恭也：反復性鼻性䯣膜炎. JOHNS 5 : 1601 1606, 1989.

3）西原信成, 湯本英二, 丘村 熙, 他：䯙液漏を伴った前頭 洞䯣膜脳㾴例. 耳鼻臨床 $84: 1249 \sim 1253,1991$.

4) Ommaya AK, Di Chiro G, Baldwin M, et al : Nontraumatic cerebrospinal fluid rhinorrhoea. J Neurol Neurosurg Psychiat $31: 214 \sim 225,1968$.

5 ) Calhoun KH, Weiner RL, Theilen FW, et al : Cerebrospinal fluid rhinorrhea 41 years after injury. Otolaryngol Head Neck Surg 98 : 90 91, 1988.

6 ) Crow HJ, Keogh C and Northfield DWC : The localization of cerebrospinal-fluid fistulae. Lancet $271: 325 \sim 327,1956$.

7 ) Charles DA and Snell D : Cerebrospinal fluid rhinorrhea. Laryngoscope $89:$ : 822 826, 1979.

8) Hasegawa M, Watanabe I, Hiratsuka $\mathrm{H}$, et al : Transfer of radioisotope from CSF to nasal secretion. Acta Otolaryngol $95: 359 \sim 364,1983$.

9 ）兵頭政光, 柳原尚明, 丘村 熙, 他 : ヒト濃縮フィブリン による髄液鼻漏の治療. 耳鼻 $31: 7 \sim 12,1985$.

10）丘村 熙, 兵頭政光, 西原信成：鼻性䯣液漏. JOHNS 7 : 735 739, 1991.

11) Meurman OH, Irjala K, Suonpaa J, et al : A new method for the identification of cerebrospinal fluid leakage. Acta Otolaryngol $87:$ 366 369, 1979. 
12) Yokoyama K, Hasegawa M, Shiba KS, et al : Diagnosis of CSF rhinorrhea; detection of tau-transferrin in nasal discharge. Otolaryngol Head Neck Surg $98: 328 \sim 332$, 1988.

13) Oberascher $G$ : Cerebrospinal fluid otorrhea; new trends in diagnosis. Am J Otol $9:$ 102 108, 1988.

14) Leech $P$ : Cerebrospinal fluid leakage, dural fistulae and meningitis after basal skull fractures. Injury $6: 141 \sim 149$, 1974.

15) Yessenow RS and McCabe BF : The osteomucoperiosteal flap in repair of cerebrospinal fluid rhinorrhea ; a 20-year experience. Otolaryngol Head Neck Surg 101 : 555 558, 1989.

16) Dohlman G: Spontaneous cerebrospinal rhinorrhea; a case operated by rhinologic methods. Acta Otolaryngol Suppl $67: 20 \sim 23,1948$.

17) Calcaterra TC : Extracranial surgical repair of cerebrospinal rhinorrhea. Ann Otol Rhinol Laryngol 89 : 108 $\sim 116,1980$.

18) Papay FA, Maggiano H, Dominquez S, et al : Rigid endoscopic repair of paranasal sinus cerebrospinal fluid fistulas. Laryngoscope $99:$ 1195 1201, 1989.

$$
\left(\begin{array}{l}
\text { 原稿受付 : 平成 } 6 \text { 年 } 9 \text { 月 } 8 \text { 日 } \\
\text { 原稿採択 : 平成 } 6 \text { 年 } 10 \text { 月 } 6 \text { 日 } \\
\text { 別刷請求先 : 兵頭政光 } \\
\text { 干791-02 愛媛県温泉郡重信町志津川 } \\
\text { 愛媛大学医学部耳鼻咽喉科学教室 }
\end{array}\right)
$$

